Стрільчук В. М., здобувач (Національний університет водного господарства та природокористування, м. Рівне)

\title{
ОБЛІГАЦІї, ЯК ФОРМА ЗДІЙСНЕННЯ ЕКОЛОГІЧНИХ IНВЕСТИЦІЙ В РЕГІОНІ
}

В статті розглядається проблема диверсифікації джерел інвестування природоохоронних інвестицій. Проведено аналіз екологічного інвестування в Херсонській області. Встановлено недофінансування природоохоронних програм в регіоні. Зазначається потреба створення організаційних структур для вдосконалення процесів вирішення екологічних проблем Херсонщини. Як інституція, що функціонуватиме з метою регулювання екологічної безпеки розглядається багатоцільовий екологічний комплекс. Наводяться особливості функціонування підприємств, що ввійдуть до складу комплексу. Розглядається можливість випуску облігацій такими підприємствами для залучення коштів у природоохоронні проекти.

Ключові слова: екологічні інвестиції, багатоцільовий екологічний комплекс, Херсонська область, облігації.

Постановка проблеми. Здійснення природоохоронної діяльності в Україні нині детермінується рівнем інвестиційного забезпечення реалізації відповідних проектів. Обмеженість бюджетного фінансування в більшості регіонів України та незначний рівень ефективності виробничо-господарської діяльності підприємств вимагають розробки принципово нових форм та методів інвестиційної діяльності у природоохоронній сфері.

Виникає необхідність в уточненні сутності, принципів та проблем інвестиційної діяльності в окремих регіонах та на рівні окремих підприємств, а також особливостей і механізмів її здійснення на ринку фінансових послуг. Проблема ускладнюється тим, що в розрізі адміністративно-територіальних одиниць України екологічних проблем значно відрізняється, що створює різні стартові умови для імплементації сучасних форм інвестування реалізації проектів модернізації, реконструкції й технічного переоснащення природоохоронної інфраструктури, в тому числі і щодо ресурсної бази емісії цінних паперів. Для активізації екологічно спрямованої інвестиційної діяльності та підвищення інвестиційної привабливості природоохоронної сфери в цілому, необхідно сформувати інституціональні передумови випуску відповідних цінних паперів, їх виходу на вторинний фондовий ринок 
та взаємодії з фінансовими посередниками.

Аналіз останніх досліджень та публікацій. У вітчизняній економічній науці найбільша увага приділена дослідженню теоретикометодологічних основ екологічної інвестиційної діяльності, яка зводиться, як правило, до бюджетного фінансування потреб окремих галузей або регіонів. Про необхідність здійснення таких інвестицій опубліковано чимало наукових праць, проведено конференцій та винесено резолюцій. Так, визнано, що Стратегія національної екологічної політики й імідж України вимагають переорієнтації економічної парадигми на користь «зеленого» зростання [1]. При цьому задачі економічного, соціального та екологічного розвитку мають бути взаємоузгодженими й визначатися з урахуванням основних принципів якісно нової ідеології суспільних перетворень.

Серед існуючого доробку в огляду на тему даного дослідження вважаємо за доцільне виділити наступні здобутки.

Насамперед, на увагу заслуговують сучасні трансформаційні процеси інвестиційного середовища, що проявляються у такому:

- трансформації оцінок інвесторами екологічних результатів інвестування;

- зростанні потреб у посередницьких послугах фінансового сектора в наслідок розвитку ринкових механізмів забезпечення сталого розвитку (вуглецевих ринків, «зелених технологій» тощо);

- репрезентативності ринкових оцінок екологічно безпечного виробництва та інвестиційній привабливості різних фінансових інструментів, особливостях їх ціноутворення.

Необхідно враховувати, що екологічно обумовлені очікування інвесторів стосовно інвестицій в екологічні виробництва та технології переорієнтують потоки капіталу у ці сфери та зумовлюють зміну пріоритетів у традиційних галузях та видах діяльності [2].

Зазначимо, що в Україні екологічні інвестиції не є пріоритетними. Дослідження Петренко І.М. показало, що в 2017 р. обсяг капітальних інвестицій, спрямованих на захист навколишнього природного середовища, значною мірою скоротився, притому що загальний обсяг капітальних інвестицій в Україні та ВВП зріс. Це свідчить про низьку зацікавленість суб'єктів господарювання у реалізації екологічних інвестицій через їх невисоку віддачу і тривалий період отримання віддачі від проекту. Немалу роль тут грає також низький рівень екологічної відповідальності в суспільстві та споживацьке ставлення українців до природних ресурсів [3].

Перспективним, на нашу думку, залишається регіональний підхід до екологічного інвестування. Стосовно окремого регіону можна 
розробити конкретні регуляторні заходи, більшість з яких є прийнятними і для інших територій. Наприклад в [4] запропоновано для Українського Причорномор'я здійснення певних заходів щодо стимулювання інвестування в природоохоронну сферу, а саме:

- впровадження проектного підходу до державного адміністрування бізнесу;

- надання цільових непрямих пільг (у вигляді знижених ставок податків) на інноваційно-інвестиційну діяльність, особливо для новостворених суб'єктів господарювання;

- максимально можливе скорочення прямих дотацій та державної фінансової підтримки суб'єктів господарювання в інноваційноінвестиційній сфері;

- делегування повноважень зі встановлення та корегування системи місцевих податків на базовий рівень місцевого самоврядування, в межах загальнодержавних норм і правил податкового законодавства;

- створення агенцій регіонального розвитку з функціями забезпечення інвестиційних проектів на засадах державно-приватного партнерства і участі таких державних агенцій в розподілі прибутку, отриманого в результаті реалізації підтримуваних проектів;

- впровадження локальної відповідальності місцевої адміністрації за успішність супроводження реалізації інноваційно-інвестиційних проектів;

- застосування методичного підходу щодо комплексної оцінки результативності реалізації інноваційно-інвестиційних проектів, заснованої на визначенні інтересів бізнесу (інвестора, реципієнта), органів державної влади, соціуму та інтересу збереження навколишнього середовища.

Існує навіть окремий науковий термін - реальні екологічні інвестиції регіону: реальні екологічні інвестиції регіону, що трактується як територіально узгоджені капітальні вкладення, що спрямовуються на створення таких прибуткових основних фондів, в процесі виробництва та експлуатації яких: по-перше, зменшується використання природних ресурсів і, по-друге, пом'якшується (чи ліквідується) негативний вплив на довкілля та здоров'я людини [5].

Проведений аналіз останніх досліджень дає нам підстави розглядати фінансування природоохоронних заходів на прикладі окремої Херсонської області, як вагомий інструмент для покращення екологічної ситуації в україні в цілому.

Мета дослідження. Дане дослідження спрямоване на дослідження стану екологічного інвестування в Херсонській області та формування на цій основі рекомендацій щодо розвитку форм фінан- 
сування природоохоронних проектів в регіоні.

Виклад основного матеріалу. Проведений нами аналіз екологічних інвестицій у Херсонській області засвідчив, що переважаючими $€$ поточні витрати. Вони становили у 2017 році 78111,8 тис. грн., або $96,1 \%$.

Херсонська область - окремий природний регіон, який включає об'єкти природно - заповідного фонду та інші території, що зберігаються конвенціями, угодами, договорами і забезпечують збереження ландшафтів і біорізноманіття. Тому в структурі витрат 40\% було спрямовано саме на збереження біорізноманіття і середовища існування. Вагомими $\epsilon$ також поточні екологічні витрати, що спрямовані на очищення зворотних вод та поводження з відходами (табл. 1).

Таблиця 1

Поточні екологічні витрати Херсонщини за напрямками природоохоронних заходів у 2017 році

\begin{tabular}{|l|l|l|}
\hline Напрямки природоохоронних заходів & \multicolumn{2}{|l|}{ Поточні витрати } \\
\cline { 2 - 3 } & тис.грн. & $\%$ \\
\hline Усього, у тому числі & 78111,8 & 100,0 \\
\hline охорона атмосферного повітря і клімату & 1712,2 & 2,2 \\
\hline очищення зворотних вод & 21743,0 & 27,8 \\
\hline поводження з відходами & 16647,4 & 21,3 \\
\hline $\begin{array}{l}\text { захист і реабілітація ґрунту, підземних і по- } \\
\text { верхневих вод }\end{array}$ & 137,9 & 0,2 \\
\hline $\begin{array}{l}\text { збереження біорізноманіття і середовища } \\
\text { існування }\end{array}$ & 31165,4 & 39,9 \\
\hline $\begin{array}{l}\text { радіаційна безпека (за винятком заходів } \\
\text { для запобігання аваріям і катастрофам) }\end{array}$ & 19,1 & 0,0 \\
\hline $\begin{array}{l}\text { Науково-дослідні роботи природоохорон- } \\
\text { ного спрямування }\end{array}$ & 6138,9 & 7,9 \\
\hline інші напрями природоохоронної діяльності & 548,0 & 0,7 \\
\hline
\end{tabular}

Капітальні інвестиції складають майже 4\%, при цьому 2457,1 тис. грн. інвестицій здійснено в основний капітал, а 752,2 тис. грн. - витрати на капітальний ремонт природоохоронного обладнання. У 2017 р. поточні витрати збільшились проти 2016р., на 5,5\%, а капітальні інвестиції - на 40,9\% відповідно.

В структурі капітальних екологічних інвестицій переважає напрям «очищення зворотних вод», що становить понад 62\% (табл. 2). 3 всього обсягу витрат на капітальний ремонт $70 \%$ було здійснено саме з цією метою. 
Капітальні екологічні інвестиції Херсонщини у 2017 році

\begin{tabular}{|l|c|c|c|}
\hline \multirow{2}{*}{ Напрямки інвестування } & \multicolumn{3}{|c|}{ Капітальні інвестиції } \\
\cline { 2 - 4 } & тис. грн. & $\%$ & $\begin{array}{c}\text { у т.ч. на капіта- } \\
\text { льнй ремонт, } \\
\text { тис. грн. }\end{array}$ \\
\hline Усього & 3209,3 & 100,0 & 752,2 \\
\hline $\begin{array}{l}\text { у тому числі охорона атмос- } \\
\text { ферного повітря і клімату }\end{array}$ & 385,2 & 12,0 & 20,0 \\
\hline очищення зворотних вод & 2014,4 & 62,8 & 520,2 \\
\hline поводження з відходами & 163,6 & 5,1 & - \\
\hline $\begin{array}{c}\text { захист і реабілітація ґрунту, } \\
\text { підземних і поверхневих вод }\end{array}$ & 121,2 & 3,8 & 121,1 \\
\hline $\begin{array}{c}\text { збереження біорізноманіття і } \\
\text { середовища існування }\end{array}$ & 434,1 & 13,5 & - \\
\hline $\begin{array}{l}\text { інші напрями природоохорон- } \\
\text { ної діяльності }\end{array}$ & 90,8 & 2,8 & 90,8 \\
\hline
\end{tabular}

За рахунок коштів Державного та місцевих бюджетів було здійснено 29,2\% поточних витрат. Освоєння капітальних інвестицій за рахунок Держбюджету у 2017 році не було. Основним джерелом фінансування витрат на охорону довкілля, як і в попередні роки, були власні кошти підприємств: на капітальні інвестиції - 59,9\% і на поточні витрати - 69,4\%.

Протягом 2017 року підприємствами, організаціями та установами м.Каховка витрачено $31,9 \%$ коштів від загальної по області суми капітальних інвестицій природоохоронного призначення, а підприємствами, організаціями та установами Чаплинського району 30,8\% - поточних витрат.

Протягом 2017 р. підприємствам, організаціям та установам області за забруднення навколишнього природного середовища і порушення природоохоронного законодавства пред'явлено екологічних платежів на загальну суму 9895,2 тис. грн., з них екологічний податок за викиди в атмосферне повітря від стаціонарних та пересувних джерел - 20,6\% (2038,5 тис. грн.), за розміщення відходів - 19,8\% (1957,6 тис. грн.), за скиди забруднювальних речовин у водойми $59,0 \%$ (5840,8 тис. грн.) та 0,6\% (58,3 тис. грн.) - штрафні санкції за порушення природоохоронного законодавства.

Вцілому протягом 2017 р. на охорону навколишнього природного середовища підприємствами, організаціями та установами Херсонської області було витрачено 81321,1 тис. грн. (без ПДВ), що 
на 6,6\% більше порівняно з 2016 р. Приведені дані свідчать, що проблема інвестування охорони довкілля залишається однією з найбільш актуальних в регіоні.

Сучасний доробок українських вчених став теоретикометодологічним підґрунтям створення системи раціонального природокористування на національному, регіональному й локальному рівнях відповідно до умов сучасних умов розвитку національної економіки. Ця система має бути спрямована на реалізацію сучасної еколого - економічної стратегії природокористування та досягнення високого рівня ресурсо-екологічної безпеки держави. Вона має ґрунтуватися на застосуванні комбінації взаємо-узгоджених цілей, засобів і еколого-економічних критеріїв прийняття рішень у сфері природокористування, природо-охорони й вирішення ресурсо-екологічних проблем з мінімальними затратами праці та коштів, а також на чітко визначених екологічних пріоритетах [6].

Однією з таким систем є багатоцільовий екологічний комплекс (БЕК) - інтегральний, динамічний комплекс, який складається 3 установ, організацій і об'єктів об'єднаних для реалізації спільної мети - мінімізації шкідливих екологічних наслідків господарської діяльності шляхом виконання специфічних функцій, притаманних кожному з елементів цього комплексу. Його характерною ознакою є цільова підпорядкованість кожного елементу загальній меті, а також наявність між елементами відповідних системоутворюючих зв'язків: інформаційних, технологічних, економічних тощо [7].

Структуровизначальними в даному комплексі $€$ екологічні зв'язки, які і є тим системоформуючим фактором, що об'єднує елементи комплексу і разом з тим, чітко розмежовує їх функції. Додамо, що екологічні зв'язки - це зв'язки, що виникають при різних видах діяльності (виробничій, інноваційній, інвестиційній, соціальній, зовнішньоекономічній тощо) з приводу використання природних ресурсів.

Функціонування підприємств у такому комплексу буде чітко регламентуватись загальними екологічними вимогами, специфічними для кожного БЕК. При цьому на більшості таких підприємств буде спостерігається низький рівень фінансового забезпечення. При входженні в комплекс більшість підприємств не зможе відмовитися від залучення зовнішніх джерел, оскільки низький рівень рентабельності не дозволятиме за рахунок власних коштів повною мірою оновлювати основний капітал. В таких умовах однією з основних складових антикризового менеджменту підприємств, що входять до складу БЕК, має стати диверсифікація зовнішніх джерел інвестиційного забезпечення виробничо-господарської діяльності. Враховуючи те, що 
банківське кредитування $€$ надзвичайно обтяжливим для суб'єктів господарювання з огляду на високі процентні ставки, варто зменшити частку банківських кредитів в портфелі зовнішніх джерел фінансового забезпечення шляхом випуску облігацій.

До основних переваг фінансування на основі емісії облігацій можна віднести такі: диверсифікація капіталодавців, зокрема кредиторів; залучення коштів здійснюється на довгостроковий період; податкові переваги, оскільки проценти за облігаціями відносяться на зменшення оподаткованого доходу емітента; порівняно з акціями облігації є менш ризиковим об'єктом вкладення коштів для інвесторів.

Також залучення коштів шляхом емісії облігацій має багато інших переваг: процентна ставка завжди може бути встановлена на рівні, що задовольняє як емітента, так і інвесторів - вище депозитної і нижче кредитної; гнучке управління боргом - емітент, в залежності від власних потреб, може змінювати параметри емісії облігацій (процентну ставку, обсяг випуску шляхом дострокового викупу частини емісії), якщо це передбачено інформацією про випуск облігацій; право вибору кредиторів - емітент вибирає коло потенційних інвесторів, яке може бути досить широким (при публічному продажу) або заздалегідь визначеним (при персоніфікованому продажу); ринковий характер позики - емітент виходить на ринок з власним фінансовим інструментом (ринкова позика тим і відрізняється від кредитів, що може бути легко переуступлена одним кредитором іншому); наявність позитивної історії випуску корпоративних облігацій на внутрішньому ринку може бути фундаментом для виходу на міжнародний ринок капіталу.

Для суб'єктів підприємництва, які функціонують у формі акціонерного товариства, значними позитивами емісії облігацій $€$ [8]:

- диверсифікація бази інвесторів, в результаті чого з'являється можливість виходу на кінцевого інвестора. Як показує досвід, навіть первинне розміщення облігацій дає емітенту приплив набагато більш дешевих фінансових коштів, у порівнянні з іншими видами кредитування;

- збільшення інформаційної відкритості та фінансової привабливості емітента для розміщення інвестицій. Так як випуск власних облігацій завжди реєструється і висвітлюється в засобах масової інформації, діяльність підприємства-емітента стає більш прозорою та доступною для зацікавлених інвесторів;

- збільшення привабливості по відношенню до інших цінних паперів емітента. Випуск власних облігацій завжди збільшує курсову вартість акцій та інших цінних паперів емітента, що гарантує успіх 
при повторних емісіях;

- перспектива зниження вартості кредитування. Випуск корпоративних облігацій та сумлінне їх обслуговування завжди збільшує рейтинг емітента в очах потенційних інвесторів і кредитних організацій, в результаті чого емітент може розраховувати на зниження процентної ставки при кредитуванні;

- можливість залучення набагато більших фінансових коштів і на більш тривалий термін, ніж при банківському кредитуванні. Тобто, емітенту надається власний фінансовий інструмент.

Серед найсуттєвіших недоліків цього інструменту фінансування найчастіше наводяться такі: порівняно високий рівень накладних витрат, пов'язаних із випуском облігацій; ризик сплати завищених процентів, передбачених умовами випуску облігацій, у разі зменшення ставок на ринку капіталів; через значну кількість держателів облігацій і широку географію їх знаходження можуть виникнути труднощі ведення переговорів з капіталодавцями у разі необхідності пролонгації строків погашення.

Облігаційна позика ніколи не розміщується просто так. У підприємства обов'язково повинна бути бізнес-ідея, оформлена у вигляді ретельно продуманого і прорахованого бізнес-плану конкретного проекту, під який потрібні кошти. Це може бути, наприклад, будівництво нового цеху, впровадження нової технологічної лінії або модернізація існуючої. Дуже важливо «вписати» передбачувану облігаційну позику в загальну стратегію БЕК.

Практика індустріально розвинених країн підтверджує, що за допомогою емісії облігацій можна мобілізувати значні фінансові ресурси для реалізації великомасштабних інвестиційних проектів, забезпечуючи їх власникам отримання стійкого процентного доходу, гарантувати його першочергову виплату (порівняно з дивідендами за акціями). Залучення позикового капіталу у формі випуску облігацій забезпечує акціонерному товариству-емітенту наступні переваги:

1. Емісія облігацій не призводить до втрати контролю над підприємством (як у випадку з випуском акцій).

2. Облігації можуть бути емітовані при відносно невисоких фінансових зобов'язаннях за відсотками (у порівнянні зі ставками відсотків за банківський кредит або нормами дивідендів за акціями).

3. Облігації мають більшу потенційну здатність поширення, ніж акції, внаслідок меншого рівня ризику для інвесторів (вкладників), оскільки забезпечені активами (майном) товариства.

4. Корпоративні облігації забезпечують залучення капіталу на тривалий термін - від одного року до десяти і більше років, що до- 
зволяє фінансувати середньострокові і довгострокові інвестиційні програми та проекти.

5. Масовий випуск надійних і привабливих облігацій при налагодженій системі їх розміщення створює потенційні можливості для залучення заощаджень населення в реальний сектор економіки, тобто трансформації доходів накопичень сімейних господарств в інвестиції. Це особливо важливо для оновлення виробництва і переходу лісогосподарських підприємств з на інноваційний шлях розвитку.

Висновки. Однією з дієвих форм диверсифікації джерел інвестиційного забезпечення природоохоронних проектів $\epsilon$ випуск підприємствами, що входять до складу багатоцільового екологічного комплексу регіону, облігацій під заставу виробленої продукції. Це дасть можливість акумулювати інвестиційні ресурси для реалізації капіталомістких екологічних проектів.

1. Резолюція II Міжнародного екологічного форуму "Зелена економіка. Зелені інвестиції. Зелений туризм". Економіст. 2014. №9. С. 58-59. URL: http://nbuv.gov.ua/UJRN/econ_2014_9_3.]. (дата звернення: 05.06.2019). 2. Похилько С. В. Інвестиційні механізми "зеленої" економіки. Mechanism of Economic Regulation. 2014. № 1. C. 131-139. URL: http://nbuv.gov.ua/UJRN/Mre_2014_1_14. (дата звернення: 05.06.2019). 3. Петренко І. П. Екологічні інвестиції та джерела їх фінансування в Україні. Науковий вісник Міжнародного гуманітарного університету. Економіка і менеджмент. 2018. Вип. 32. C. 62-68. URL: http://nbuv.gov.ua/UJRN/Nvmgu_eim_2018_32_12. (дата звернення: 05.06.2019). 4. Лайко 0. І., Чехович 3. В. Інвестиційно-інноваційні важелі забезпечення соціально-економічного "зеленого" розвитку Українського Причорномор'я. Економічні інновації. 2014. Вип. 58. С. 166-175. URL: http://nbuv.gov.ua/UJRN/ecinn_2014_58_18. (дата звернення: 05.06.2019). 5. Квактун 0. О. Реальні екологічні інвестиції як дієвий інструмент сталого проектування та будівництва регіонів України. Економічний простір. 2014. № 83. C. 68-77. URL: http://nbuv.gov.ua/UJRN/ecpros_2014_83_9. (дата звернення: 05.06.2019). 6. Надоша 0. В. Теоретико-методологічний аналіз сталого розвитку у контексті сучасних дослідницьких підходів. Державне управління: удосконалення та розвиток. 2011. № 10. URL: http://nbuv.gov.ua/UJRN/Duur_2011_10_4 (дата звернення: 05.06.2019). 7. Савіна Н. Б., Ковшун Н. Е. Багатоцільовий екологічний комплекс як організаційно-господарська структура прибережних територій. Містобудівне планування і управління прибережними територіями : матеріали міжнародної науково-практичної конференції, 19-20 вересня 2016 р., смт Сергіївка, Одеська обл. Одеса, 2016. С. 101-102. 8. Мельник Т. Випуск боргових зобов'язань як важлива складова диверсифікації джерел інвестиційного забезпечення розвитку регіональних лісогосподарських комплексів. Економіст. 2012. № 12. С. 55-57. 


\section{REFERENCES:}

1. Rezoliutsiia II Mizhnarodnoho ekolohichnoho forumu "Zelena ekonomika. Zeleni investytsii. Zelenyi turyzm". Ekonomist. 2014. № 9. S. 58-59. URL: http://nbuv.gov.ua/UJRN/econ_2014_9_3.]. (data zvernennia: 05.06.2019). 2. Pokhylko S. V. Investytsiini mekhanizmy "zelenoi" ekonomiky. Mechanism of Economic Regulation. 2014. № 1. S. 131-139. URL: http://nbuv.gov.ua/UJRN/Mre_2014_1_14. (data zvernennia: 05.06.2019). 3. Petrenko I. P. Ekolohichni investytsii ta dzherela yikh finansuvannia v Ukraini. Naukovyi visnyk Mizhnarodnoho humanitarnoho universytetu. Ekonomika $i$ menedzhment. 2018. Vyp. 32. S. 62-68. URL: http://nbuv.gov.ua/UJRN/Nvmgu_eim_2018_32_12. (data zvernennia: 05.06.2019). 4. Laiko O. I., Chekhovych Z. V. Investytsiino-innovatsiini vazheli za-bezpechennia sotsialno-ekonomichnoho "zelenoho" rozvytku Ukrainskoho Prychornomoria. Ekonomichni innovatsii. 2014. Vyp. 58. S. 166-175. URL: http://nbuv.gov.ua/UJRN/ecinn_2014_58_18. (data zvernennia: 05.06.2019). 5. Kvaktun 0. 0. Realni ekolohichni investytsii yak diievyi instrument staloho proektuvannia ta budivnytstva rehioniv Ukrainy. Ekonomichnyi prostir. 2014. № 83. S. 68-77. URL: http://nbuv.gov.ua/UJRN/ecpros_2014_83_9. (data zvernennia: 05.06.2019). 6. Nadosha 0. V. Teoretyko-metodolohichnyi analiz staloho rozvytku u konteksti suchasnykh doslidnytskykh pidkhodiv. Derzhavne upravlinnia: udoskonalennia ta rozvytok. 2011. № 10. URL: http://nbuv.gov.ua/UJRN/Duur_2011_10_4 (data zvernennia: 05.06.2019). 7. Savina N. B., Kovshun N. E. Bahatotsilovyi ekolohichnyi kompleks yak orhani-zatsiino-hospodarska struktura pryberezhnykh terytorii. Mistobudivne pla-nuvannia i upravlinnia pryberezhnymy terytoriiamy : materialy mizhnarodnoi naukovo-praktychnoi konferentsii, 19-20 veresnia 2016 r., smt Serhiivka, Odeska obl. Odesa, 2016. S. 101-102. 8. Melnyk T. Vypusk borhovykh zoboviazan yak vazhlyva skladova dyversyfikatsii dzherel investytsiinoho zabezpechennia rozvytku rehionalnykh lisohospodarskykh kompleksiv. Ekonomist. 2012. № 12. S. 55-57.

Рецензент: д.е.н., професор Грицюк П. М. (НУВГП)

Strilchuk V. M., Applicant (National University of Water and Environmental Engineering, Rivne)

TENDERS AS A FORM OF ENVIRONMENTAL IMPLEMENTATION REGIONAL INVESTMENT

The article deals with the problem of expansion of sources of financing in environmental investments. It was conducted an analysis of ecological investment in the Kherson region. The under-funding of 
environmental programs in the region is established. There is a need to create organizational structures for improving the processes of solving environmental problems in Kherson region. It is considered that an institution will operate in order to regulate environmental safety and a multifunctional ecological complex. The peculiarities of functioning of the enterprises are presented. The possibility of issuing bonds by such enterprises for funds attraction in environmental projects is considered.

Keywords: environmental investments, ecological investments, multipurpose ecological complex, Kherson oblast, bonds, environmental projects.

Стрильчук В. М., соискатель (Национальный университет водного хозяйства и природопользования, г. Ровно)

\section{ОБЛИГАЦИИ КАК ФОРМА ОСУЩЕСТВЛЕНИЯ ЭКОЛОГИЧЕСКИХ ИНВЕСТИЦИЙ В РЕГИОНЕ}

В статье рассматривается проблема диверсификации источников инвестирования природоохранных инвестиций. Проведен анализ экологического инвестирования в Херсонской области. Установлено недофинансирование природоохранных программ в регионе. Отмечается необходимость создания организационных структур для совершенствования процессов решения экологических проблем Херсонщины. Как институт, который будет функционировать в целях регулирования экологической безопасности, рассматривается многоцелевой экологический комплекс. Приводятся особенности функционирования предприятий, которые войдут в состав комплекса. Рассматривается возможность выпуска облигаций такими предприятиями для привлечения средств в природоохранные проекты.

Ключевые слова: экологические инвестиции, многоцелевой экологический комплекс, Херсонская область, облигации. 